\title{
Seroprevalence of hepatitis B virus, hepatitis $C$ virus and human immunodeficiency virus in the western region of Nepal
}

\author{
Umid Kumar Shrestha*, Bhup Dev Bhatta \\ Manipal College of Medical Sciences, Pokhara, Nepal
}

\section{DOI Name}

http://dx.doi.org/10.3126/jaim.v5i1.17064

\section{Keywords}

Seroprevalence; HBV; HCV; HIV; alcoholic liver disease

\section{Citation}

Umid Kumar Shrestha, Bhup Dep Bhatta. Seroprevalence of hepatitis B virus, hepatitis C virus and human Immunodeficiency virus in the western region of Nepal. Journal of Advances in Internal Medicine 2016;05(01):6-10

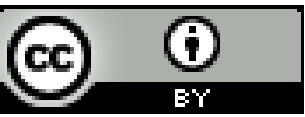

This work is licensed under a Creative Commons Attribution 3.0 Unported License.

\begin{abstract}
Background and aims: The hepatitis B virus (HBV), hepatitis $\mathrm{C}$ virus (HCV) and human immunodeficiency virus (HIV) are associated with major public health concerns. The aim of the study was to determine the seroprevalence of HBV, $\mathrm{HCV}$ and HIV in the western region of Nepal.

Methods: This was a cross-sectional observational study, in which 15,791 patients, attending to Manipal Teaching Hospital, Pokhara, Nepal, were investigated for HBV, HCV and HIV from June 2013 to March 2016; demographic and biochemical profile were studied among the patients with positive test results.

Results: Among 15,791 patients [male 6614 (41.9\%) and female 9177 (58.1\%)], HBV was found in 180 (1.1\%), HCV in 52 (0.3\%) and HIV in 77 (0.5\%). The HBV was found in $63.9 \%$ of males and $36.1 \%$ of females, HCV in $67.3 \%$ of males and $32.7 \%$ of females, and HIV in $61 \%$ of males and $39 \%$ of females which showed that males had more positivity of HBV $(P<0.001), H C V(P<0.001)$ and HIV $(P$ 0.001 ) than that of female. The HBV was found more in 20-29 years age group (27.2\%), HCV in $30-39$ years (32.7\%), and HIV in $40-49$ years (28.6\%), with all having $p<0.001$. Among the patients of HBV, HCV and HIV, the mean values of total bilirubin were $1.4 \mathrm{mg} / \mathrm{dl}, 0.8 \mathrm{mg} / \mathrm{dl}$ and $2.6 \mathrm{mg} / \mathrm{dl}$, Aspartate Transaminase $75.9 \mathrm{U} / \mathrm{L}, 54.3 \mathrm{U} / \mathrm{L}$ and $92.7 \mathrm{U} / \mathrm{L}$, Alanine Transaminase $54.6 \mathrm{U} / \mathrm{L}, 55.5 \mathrm{U} / \mathrm{L}$ and 56.1 U/L, and Alkaline Phosphatase 124.2 U/L, 109.2 U/L and 107.2 U/L, respectively. The majority of patients with $\mathrm{HCV}$ had a history of intravenous drug abuse and HIV had concomitant alcoholic liver disease.

Conclusion: The HBV was more prevalent followed by HIV and HCV in the western region of Nepal with more prevalence seen in males than in females. Regular screening of HBV, HCV and HIV among the selected patients can help detecting many new cases in Nepal.
\end{abstract}

\section{INTRODUCTION}

Hepatitis B virus (HBV), hepatitis C virus (HCV) and human immunodeficiency virus (HIV) are the three most common chronic viral pathogens of major public health concerns having similar routes of transmission, such as blood and blood products, sharing of needles to inject drugs and sexual activity) are; all of them are associated with increasing morbidity and mortality. ${ }^{1,2}$
The HBV and HCV infection lead to chronic liver diseases, especially cirrhosis and hepatocellular carcinoma. ${ }^{3}$ On the other hand, HIV causes Acquired Immunodeficiency Syndrome (AIDS), which is a serious disorder of the immune system in which the body's normal defense against infection

\footnotetext{
* Corresponding author

Umid Kumar Shrestha, MD, PhD

Department of Medicine

Manipal College of Medical Sciences, Pokhara, Nepal

umidshrestha@gmail.com
} 
is compromised, resulting into the life-threatening infections.

Viral hepatitis B and hepatitis C are significant global health issues. It is estimated that about 2 billion people are exposed to hepatitis B worldwide, with 350 million suffering from chronic infection. Similarly, more than 200 million people are estimated to be suffering from chronic infection with hepatitis $C$ throughout the world. Moreover, hepatitis B is estimated to result in 563,000 deaths annually versus 366,000 deaths for hepatitis $\mathrm{C}$ worldwide. ${ }^{3}$

More than 30 million people around the world have died of AIDS-related diseases and around 34 million people were living with HIV/AIDS in 2010. Moreover, in 2010, 2.7 million people were newly infected with HIV, and 1.8 million people died of AIDS related causes. ${ }^{4}$

We are entering in the new era of globalization where the geographical boundary between the countries is nonexistence and its impact on the health sector is unavoidable. Hence, the increasing global prevalence of HBV, HCV and HIV can affect the prevalence in Nepal as well. There are variable data about their study in different populations in Nepal, ${ }^{5-15}$ but there is a lacking of their recent, complete and valid data in Nepal; hence, we aimed to study the seroprevalence of HBV, HCV and HIV in the western region of Nepal.

\section{METHODS:}

This was a cross-sectional observational study, in which 15,791 patients, attending to Manipal Teaching Hospital, Pokhara, Nepal, were investigated for HBV, HCV and HIV from June 2013 to March 2016. Among the patients with positivity on these tests, demographic and biochemical profile were studied. The informed consent was taken from the patients and the study protocol was approved from the ethics committee of the hospital.

Demographic profile included analysis of age and sex of the patients. The age was divided into different group of less than 10 years, 10-19 years, 20-29 years, 30-39 years, 40-49 years, 50-59 years and equal or more than 60 years. The prevalence of HBV, HCV ad HIV in the male was compared with that in the female. In the patients with positive the test results, the history regarding the alcohol intake was taken by asking the CAGE questionnaire, and those with 2 or more than 2 score on questionnaire were considered as having significant alcohol consumption; they were also investigated for the biochemical profile, which included random blood sugar, total protein, albumin, total bilirubin, AST, ALT, ALP, blood urea, and serum creatinine.

The HBV, HCV and HIV were tested by kits HEPACARD, HCV TRI-
DOT and HIV TRI-DOT (J. Mitra \& Co. Pvt. Ltd, New Delhi, India; www.jmitra.co.in), respectively.

HBV test: HEPACARD is a visual, rapid, sensitive and accurate one step immunoassay for qualitative detection of Hepatitis B Surface Antigen ( $\mathrm{HBsAg}$ ) in human serum or plasma; the assay is intended to be used as an aid in the recognition and diagnosis of acute infections and chronic infectious carriers of the HBV.

HCV test: The $4^{\text {th }}$ Generation HCV TRI-DOT is a rapid, visual, sensitive and qualitative in vitro diagnostic test for the detection of antibodies to Hepatitis C Virus in human serum or plasma; the test is designed with increased sensitivity for core and NS3 antibodies using a unique combination of modified HCV antigens. They are for the putative core (structural), protease/helicase NS3 (non-structural), NS4 (non-structural) and replicase NS5 (non-structural) regions of the virus in the form of two test dots " $T_{1}$ " \& " $T_{2}$ " to provide a highly sensitive and specific diagnostic test.

HIV test: HIV TRI-DOT test is a visual, rapid, sensitive and accurate immunoassay for the differential detection of HIV1 \& HIV-2 antibodies (IgG) in human serum of plasma using HIV-1 \& HIV-2 Antigens immobilized on an immunofiltration membrane; the test is a screening test for anti-HIV-1 and antiHIV-2 and is for in vitro diagnostic use only.

The distribution of HBV, HCV and HIV was recorded according to the gender, age group and biochemical profile. The statistical analysis was done with SPSS 20.0 software (SPSS Inc., Chicago, IL, USA). The odds ratio (OR) and $95 \%$ confidence interval (CI) were calculated for gender and different age groups. The $p$ value was derived using the chi square test and a $p$ value of $<0.05$ was considered statistically significant.

Results: Among 15,791 patients, males were 6614 (41.9\%) and females were 9177 (58.1\%). The gender wise age group distribution of the patients subjected for tests of HBV, HCV and $\mathrm{HIV}$ is shown in Table 1. The study showed that HBV was present in 180 (1.1\%), HCV in 52 (0.3\%) and HIV in 77 (0.5\%), patients. Moreover, HBV was found in $63.9 \%$ of males and $36.1 \%$ of females [Odds Ratio (OR) 1.54, 95\% Confidence Interval (Cl) $1.37-1.72, \mathrm{P}<0.001$ ], HCV in $67.3 \%$ of males and $32.7 \%$ of females (OR 1.61, 95\% Cl 1.33 - 1.95, P<0.001), and HIV in 61\% of males and $39 \%$ of females (OR 1.46, 95\% Cl $1.22-1.75$, P $0.001)$, which showed that the males had more positivity of HBV, HCV and HIV than that of female $(p<0.001)$. The gender wise distribution of the patients with positive results of HBV, HCV and HIV is shown in Table 2. The OR and $95 \% \mathrm{Cl}$ of HIBV, HCV and HIV in males are shown in Table 3.

The HBV was found more in 20-29 years age group (27.2\%) [OR $1.79,95 \% \mathrm{Cl} 1.19-2.70], \mathrm{HCV}$ in $30-39$ years age group (32.7\%) 
[OR 2.95, 95\% Cl 1.65-5.27], and HIV in 40-49 years age group (28.6\%) [OR 3.56, 95\% Cl 2.16-5.85], with all having $p<0.001$. The age group distribution of the patients with positive results of HBV, HCV and HIV is shown in Table 4.

Among the patients of HBV, HCV and HIV, the mean values of total bilirubin were $1.4 \mathrm{mg} / \mathrm{dl}, 0.8 \mathrm{mg} / \mathrm{dl}$ and $2.6 \mathrm{mg} / \mathrm{dl}$, AST 75.9 U/L, 54.3 U/L and 92.7 U/L, ALT 54.6, 55.5 and 56.1, ALP $124.2 \mathrm{U} / \mathrm{L}, 109.2 \mathrm{U} / \mathrm{L}$ and $107.2 \mathrm{U} / \mathrm{L}$, blood urea $36.9 \mathrm{mg} /$ $\mathrm{dl}, 27.8 \mathrm{mg} / \mathrm{dl}$ and $36.6 \mathrm{mg} / \mathrm{dl}$, and serum creatinine $1.4 \mathrm{~g} /$ $\mathrm{dl}, \quad 0.9 \mathrm{mg} / \mathrm{dl}$ and $1.4 \mathrm{mg} / \mathrm{dl}$, respectively. The majority of patients with HIV had a history of significant consumption of alcohol resulting into the alcoholic hepatitis. The mean value of biochemistry in patients with positive results of HBV, HCV and HIV is shown in Table 5.

Results: Among 15,791 patients [male 6614 (41.9\%) and female 9177 (58.1\%)], HBV was found in 180 (1.1\%), HCV in $52(0.3 \%)$ and HIV in 77 (0.5\%). The HBV was found in 63.9\% of males and $36.1 \%$ of females, HCV in $67.3 \%$ of males and $32.7 \%$ of females, and HIV in $61 \%$ of males and $39 \%$ of females which showed that males had more positivity of HBV [Odds Ratio (OR) 1.54, 95\% Confidence Interval (Cl) 1.37 - 1.72, $\mathrm{P}<0.001$ ], HCV (OR 1.61, 95\% Cl $1.33-1.95, \mathrm{P}<0.001$ ) and HIV (OR 1.46, 95\% Cl $1.22-1.75$, P 0.001) than that of female. The HBV was found more in $20-29$ years age group (27.2\%) [OR $1.79,95 \% \mathrm{Cl} 1.19-2.70$ ], HCV in $30-39$ years (32.7\%) [OR 2.95, $95 \% \mathrm{Cl} 1.65-5.27$ ], and HIV in 40-49 years (28.6\%) [OR 3.56, $95 \% \mathrm{Cl} 2.16-5.85]$, with all having $\mathrm{p}<0.001$. Among the patients of $\mathrm{HBV}, \mathrm{HCV}$ and HIV, the mean values of total bilirubin were $1.4 \mathrm{mg} / \mathrm{dl}, 0.8 \mathrm{mg} / \mathrm{dl}$ and $2.6 \mathrm{mg} / \mathrm{dl}$, Aspartate Transaminase $75.9 \mathrm{U} / \mathrm{L}, 54.3 \mathrm{U} / \mathrm{L}$ and $92.7 \mathrm{U} / \mathrm{L}$, Alanine Transaminase 54.6 $\mathrm{U} / \mathrm{L}, 55.5 \mathrm{U} / \mathrm{L}$ and $56.1 \mathrm{U} / \mathrm{L}$, and Alkaline Phosphatase 124.2 $\mathrm{U} / \mathrm{L}, 109.2 \mathrm{U} / \mathrm{L}$ and $107.2 \mathrm{U} / \mathrm{L}$, respectively. The majority of $\mathrm{HCV}$ was found among drug addicts using the intravenous drug use, whereas the majority of patients with HIV had a history of significant consumption of alcohol resulting into the alcoholic liver disease.

Table 1: Gender wise age group distribution of the patients subjected for tests of HBV, HCV and HIV

\begin{tabular}{|l|l|l|l|}
\hline $\begin{array}{l}\text { Age group } \\
\text { (years) }\end{array}$ & $\begin{array}{l}\text { Male } \\
6614(41.9 \%)\end{array}$ & $\begin{array}{l}\text { Female } \\
9177(58.1 \%)\end{array}$ & $\begin{array}{l}\text { Total } \\
15791\end{array}$ \\
\hline$<10$ & $363(5.5 \%)$ & $199(2.2 \%)$ & $562(3.6 \%)$ \\
\hline $10-19$ & $612(9.3 \%)$ & $959(10.5 \%)$ & $1571(9.9 \%)$ \\
\hline $20-29$ & $1414(21.4 \%)$ & $4304(46.9 \%)$ & $5718(36.2 \%)$ \\
\hline $30-39$ & $915(13.8 \%)$ & $1329(14.8 \%)$ & $2244(14.2 \%)$ \\
\hline $40-49$ & $865(13.9 \%)$ & $746(8.1 \%)$ & $1611(10.2 \%)$ \\
\hline $50-59$ & $860(13 \%)$ & $619(6.7 \%)$ & $1479(9.4 \%)$ \\
\hline$>=60$ & $1585(24 \%)$ & $1021(11.1 \%)$ & $2606(16.5 \%)$ \\
\hline
\end{tabular}

Table 2: Gender wise distribution of the patients with positive results of HBV, HCV and HIV

\begin{tabular}{|l|l|l|l|l|}
\hline & $\begin{array}{l}\text { Male } \\
6614(41.9 \%)\end{array}$ & $\begin{array}{l}\text { Female } \\
9177(58.1 \%)\end{array}$ & $\begin{array}{l}\text { Total } \\
15791\end{array}$ & $P$ \\
\hline HBV & $115(63.9 \%)$ & $65(36.1 \%)$ & $180(1.1 \%)$ & $<0.001$ \\
\hline HCV & $35(67.3 \%)$ & $17(32.7 \%)$ & $52(0.3 \%)$ & $<0.001$ \\
\hline HIV & $47(61 \%)$ & $30(39 \%)$ & $77(0.5 \%)$ & 0.001 \\
\hline
\end{tabular}

Table 3: The OR and $95 \% \mathrm{Cl}$ of HBV, HCV and HIV in males

\begin{tabular}{|l|l|l|}
\hline & OR for males $(95 \% \mathrm{Cl})$ & $\mathrm{P}$ \\
\hline HBV & $1.54(1.37-1.72)$ & $<0.001$ \\
\hline HCV & $1.61(1.33-1.95)$ & $<0.001$ \\
\hline HIV & $1.46(1.22-1.75)$ & 0.001 \\
\hline
\end{tabular}

OR Odds Ratio, $95 \% \mathrm{Cl}$ Confidence Interval

Table 4: Age group distribution of the patients with positive results of HBV, HCV and HIV

\begin{tabular}{|l|l|l|l|}
\hline $\begin{array}{l}\text { Age group } \\
\text { (years) }\end{array}$ & $\begin{array}{l}\mathrm{HBV} \\
\mathrm{N}=180\end{array}$ & $\begin{array}{l}\mathrm{HCV} \\
\mathrm{N}=52\end{array}$ & $\begin{array}{l}\mathrm{HIV} \\
\mathrm{N}=77\end{array}$ \\
\hline$<10$ & $2(1.1 \%)$ & $1(1.9 \%)$ & $1(1.3 \%)$ \\
\hline $10-19$ & $8(4.4 \%)$ & $1(1.9 \%)$ & $3(3.9 \%)$ \\
\hline $20-29$ & $49(27.2 \%)$ & $14(26.9 \%)$ & $13(16.9 \%)$ \\
\hline $30-39$ & $35(19.4 \%)$ & $17(32.7 \%)$ & $20(26 \%)$ \\
\hline $40-49$ & $25(13.9 \%)$ & $10(19.2 \%)$ & $22(28.6 \%)$ \\
\hline $50-59$ & $28(15.6 \%)$ & $6(11.5 \%)$ & $12(15.6 \%)$ \\
\hline$>=60$ & $33(18.3 \%)$ & $3(5.8 \%)$ & $6(7.8 \%)$ \\
\hline
\end{tabular}

$\mathrm{P}$ by chi-square test $<0.001$

Table 5: Mean value of biochemistry in patients with positive results of HBV, HCV and HIV

\begin{tabular}{|l|l|l|l|l|}
\hline Biochemical parameter & $\begin{array}{l}\text { HBV } \\
180\end{array}$ & $\begin{array}{l}\text { HCV } \\
52\end{array}$ & $\begin{array}{l}\text { HIV } \\
77\end{array}$ & $\begin{array}{l}\text { Total } \\
309\end{array}$ \\
\hline Random Blood Sugar (mg/dl) & 108.9 & 119.0 & 109.6 & 110.9 \\
\hline Total Protein (g/dl) & 6.9 & 6.8 & 7.0 & 6.9 \\
\hline Albumin (g/dl) & 3.7 & 3.5 & 3.4 & 3.6 \\
\hline Total Bilirubin (mg/dl) & 1.4 & 0.8 & 2.6 & 1.6 \\
\hline AST (U/L) & 75.9 & 54.3 & 92.7 & 76.5 \\
\hline ALT (U/L) & 54.6 & 55.5 & 56.1 & 54.9 \\
\hline ALP (U/L) & 124.2 & 109.2 & 107.2 & 116.9 \\
\hline Urea (mg/dl) & 36.9 & 27.8 & 36.6 & 34.2 \\
\hline Creatinine (mg/dl) & 1.4 & 0.9 & 1.4 & 1.3 \\
\hline
\end{tabular}

$\mathrm{P}$ by chi square test $<0.05$

\section{Discussion:}

In the previous study done in Nepal in 1990 showed the prevalence of $\mathrm{HBsAg}$ positivity among 2,555 healthy individuals to be $0.9 \%$ ( $1.5 \%$ in male, $0.5 \%$ in female). ${ }^{5}$ In a study done among blood donors in Nepal in 2008 showed the overall seroprevalence rates of $\mathrm{HBV}$ and $\mathrm{HCV}$ were $0.82 \%$ and $0.47 \%$, respectively. In another study done among blood donors in 
different parts of Nepal in 2010 showed that the prevalence of HBV was $1.2 \%$ in Banke, $0.87 \%$ in Biratnagar and $0.35 \%$ in Kaski, and that of HCV was $0.26 \%$ in Morang, $0.16 \%$ in Kaski and $0.11 \%$ in Banke. ${ }^{10}$ Another study done in Nepal in 2013 showed the prevalence of HCV and HIV to be $0.17 \%$ and $0.71 \%$, respectively among the blood donors. ${ }^{12}$ Our study showed the prevalence of HBV to be $1.1 \%$, HCV $0.3 \%$ and HIV $0.5 \%$ among 15,791 patients attending to the hospital, which is not very different from the previous studies done in Nepal although the study sample was different among those studies.

The seroprevalence of HBV, HCV and HIV was found to be $0.887 \%, 0.101 \%$ and $0.154 \%$, respectively in voluntary blood donors in a study done in Western India. ${ }^{16}$ In other different Indian studies, HCV seroprevalence ranged between 0.57 to $1.49 \%, \%),{ }^{17-21}$ while the study done in Kolkata showed the HCV prevalence of $(0.35 \%)$. (Kolkata), which is similar to our study $(0.3 \%) .^{22}$

The prevalence of HIV was shown to be $0.55 \%$ in 1995 in New Delhi, and $0.53 \%$ in 2008 in Bhopal, which is again similar to our study $(0.5 \%)$. $^{19,20}$

The African countries have reported the seroprevalence of $\mathrm{HBV}, \mathrm{HCV}$ and HIV in their studies. The overall seroprevalence of HBV, HCV and HIV, among blood donors was $4.7 \%, 0.7 \%$ and $3.8 \%$, respectively in Ethiopia. ${ }^{23}$ In Nigeria, the seroprevalence of HBV, HCV and HIV, among the antenatal women were $3.4 \%, 2.6$ and $12.4 \%$, respectively. ${ }^{24}$ The average prevalence of HBsAg was $3.7 \%$, anti-HCV $0.9 \%$, and anti-HIV $0.15 \%$ among blood donors in Tripoli. ${ }^{25}$

Our study revealed that the prevalence of HBV, HCV and HIV was more in male than that in female with the odds ratio of 1.54 for HBV ( $95 \% \mathrm{Cl} 1.37-1.72), 1.61$ for $\mathrm{HCV}(95 \% \mathrm{Cl}$ 1.33 - 1.95) and 1.46 for $\operatorname{HIV~}(95 \% \mathrm{Cl} 1.22-1.75)$, which was statistically significant. Hence, it could be expected that more males contracted those viruses in the western region of Nepal because of their more exposure to the blood and blood products, sharing of needles to inject drugs and sexual activity. The odds ratio of HBV in 20-29 years age group was 1.79 (95\%
$\mathrm{Cl} 1.19-2.70)$, that of $\mathrm{HCV}$ in $30-39$ years was 2.95 (95\% Cl 1.655.27), and that of HIV in 40-49 years was $3.56(95 \% \mathrm{Cl} 2.16$ 5.85), with all having $p<0.001$. This showed that HBV occurred more in relatively younger age group in comparison to HCV and HIV in the western region of Nepal.

In our study, the liver enzymes (AST and ALT) in all of HBV, HCV and HIV groups were raised. This raised liver enzymes in HBV and HCV group could be because of the chronic infection of the liver caused by the virus, whereas that in HIV group could be because of the concomitant alcoholic liver disease because majority of HIV was found among the population with the history of significant alcoholic consumption leading to the alcoholic liver disease. Moreover, majority of HCV was found among drug addicts using the intravenous drug abuse,

In order to prevent or decrease the incidence of those dreadful HBV, HCV and HIV infections, it is important to make the public aware of the risks of contracting those viruses with the exposure to the unscreened blood and blood products, sharing of needles to inject drugs and unprotected sexual activity.

Our study was not without limitations. The HBV, HCV and HIV were tested by kits HEPACARD, HCV TRI-DOT and HIV TRIDOT, respectively; the tests were not repeated with other confirmatory tests. However, the quality of the kits were verified by internal and external evaluation which ensured the sensitivity and specificity of the tests being more than $99 \%$. Since this was only cross-sectional observational study, the course of the disease caused by the infection could not be followed up.

In conclusion, HBV was more prevalent followed by HIV and $\mathrm{HCV}$ in the western region of Nepal with more prevalence seen in males than in females. Regular screening of HBV, HCV and HIV among the selected patients can help detecting many new cases in Nepal. Moreover, as the majority of patients with HIV also had alcoholic liver disease, regular screening for HIV is advised in patients presenting with alcoholic liver disease in Nepal.

Conflict of interest: none declared.

sectional epidemiological study of HBV, HCV, HDV and HEV prevalence in the SubCarpathian and SouthEastern regions of Romania. J Gastrointestin Liver Dis 2010;19:43-8.

4. Patton GC, Coffey C, Sawyer SM, et al. Global patterns of mortality in young people: a systematic analysis of population health data. Lancet 2009;374: 881-92.

5. Shrestha SM. Seroepidemiology of hepatitis B in Nepal. J Commun Dis 1990;22:27-32. 
6. Sawayama Y, Hayashi J, Ariyama I, et al. A ten year serological survey of hepatitis $A, B$ and $C$ viruses infections in Nepal. J Epidemiol. 1999;9:350-4.

7. Gurubacharya DL, KC M, Karki DB. Knowledge, attitude and practices among health care workers on needle-stick injuries. Kathmandu Univ Med J 2003;1:91-4.

8. Karki S, Ghimire P, Tiwari BR, et al. Trends in hepatitis B and hepatitis $C$ seroprevalence among Nepalese Blood donors. Jpn J Infect Dis 2008;61:324-6.

9. Koirala SR, Malla RR, Khakurel S, et al. Prevalence of Hepatitis B, Hepatitis C and HIV Infections among Chronic Renal Failure Patients on Hemodialysis. Postgraduate Medical Journal of NAMS 2009;9:6-13.

10. Tiwari BR, Ghimire P, Kandel SR, et al. Seroprevalence of HBV and HCV in blood donors: A study from regional blood transfusion services of Nepal. Asian J Transfus Sci. 2010;4:91-3. doi:10.4103/0973-6247.67026

11. Shrestha SM, Shrestha S. Chronic hepatitis B in Nepal: an Asian country with low prevalence of HBV infection. Trop Gastroenterol. 2012;33:95-101.

12. Pandeya D R. Sero Prevalence of HIV, Hepatitis B, Hepatitis C and Syphilis Among Blood Donors in Kathmandu, Nepal. Sex Transm Infect 2013;89:A227-A228 doi:10.1136/ sextrans-2013-051184.0709.

13. Bhattarai $S, K C S$, Pradhan $P$, et al. Hepatitis $B$ vaccination status and Needle-stick and Sharps-related Injuries among medical school students in Nepal: a cross-sectional study. BMC Res Notes. 2014;7:774. doi:10.1186/1756-0500-7774.

14. Supram HS, Gokhale S, Sathian B et al. Hepatitis B Virus (HBV) and Hepatitis C Virus (HCV) Co-infection among HIV infected individuals at tertiary care hospital in western Nepal. Nep Jour Epidemol. 2015;5(2);488-93.

15. Kinkel HT, Karmacharya D, Shakya J, et al. Prevalence of HIV, Hepatitis B and C Infections and an Assessment of HCV Genotypes and Two IL28B SNPs among People Who Inject Drugs in Three Regions of Nepal. PLoS ONE 2015;10:e0134455. doi:10.1371/journal.pone.0134455.

16. Shah N, Shah JM, Jhaveri P, et al. Sero prevalence of HBV,
HCV, HIV and syphilis among blood donors at a tertiary Care Teaching Hospital in Western India. Gujarat Medical Journal 2013;68: 2:35-9.

17. Mathai J, Sulochana PV, Satyabhama S, et al. Profile of transfusion transmissible infections and associated risk factors among blood donors of Kerala. Indian J Pathol Microbiol 2002;45:319-22.

18. Shrikrishna A, Sitalakshmi S, Prema Damodar S. How safe are our safe donors? Indian J Pathol Microbiol 1999;42:411-6.

19. Nanu A Sharma SP, Chatterjee K, et al. Markers for transfusion-transmissible infections in north Indian voluntary and replacement blood donors: Prevalence and trends 1989-1996.Vox Sang1997;73:70-3.

20. Sawke N, Sawke GK, Chawla S. Seroprevalence of Common Transfusion - Transmitted infections among Blood Donors. People's Journal of Scientific Research 2010;3:5-8.

21. Gupta N, Kumar V, Kaur A. Seroprevalence of HIV, HBV, $\mathrm{HCV}$ and syphilis in voluntary blood donors. Indian J Med Sci 2004;58:255-7.

22. Das B K, Gayen B K, Aditya S, et al. Seroprevalence of Hepatitis B, Hepatitis $C$, and human immunodeficiency virus among healthy voluntary first-time blood donors in Kolkata. Ann Trop Med Public Health 2011;4:86-90.

23. Tessema B, Yismaw G, Kassu A, et al. Seroprevalence of $\mathrm{HIV}, \mathrm{HBV}, \mathrm{HCV}$ and syphilis infections among blood donors at Gondar University Teaching Hospital, Northwest Ethiopia: declining trends over a period of five years. BMC Infect Dis 2010;10:111. doi:10.1186/1471-2334-10111.

24. Ikeako LC, Ezegwui HU, Ajah LO, et al. Seroprevalence of Human Immunodeficiency Virus, Hepatitis B, Hepatitis C, Syphilis, and Co-infections among Antenatal Women in a Tertiary Institution in South East, Nigeria. Ann Med Health Sci Res 2014;4: 954-8. doi: 10.4103/2141-9248.144925

25. Daw MA, Shabash A, El-Bouzedi A, et al. Seroprevalence of HBV, HCV \& HIV Co-Infection and Risk Factors Analysis in Tripoli-Libya. PLoS ONE 2014;9:e98793. doi:10.1371/ journal.pone.0098793. 